\title{
Friction Stir Welding of Dissimilar AA6061-T6 to AZ31B-H24 Alloys
}

Rocio Saldaña-Garcés ${ }^{1}$, Daniela Hernández-García², Felipe García-Vázquez ${ }^{3}$, Emmanuel José Gutiérrez-Castañeda ${ }^{4}$ David Verdera ${ }^{5}$, Rogelio Deaquino-Lara6 ${ }^{6}$ (D)

${ }^{1}$ Consejo Nacional de Ciencia y Tecnologia - CONACYT, Corporación Mexicana de Investigación en Materiales, Posgrado en Soldadura, Saltillo, Coahuila, México.

${ }^{2}$ Corporación Mexicana de Investigación en Materiales, Saltillo, Coahuila, México.

${ }^{3}$ Universidad Autónoma de Coahuila, Facultad de Ingeniería, Arteaga, Coahuila, México.

${ }^{4}$ Consejo Nacional de Ciencia y Tecnologia - CONACYT, Universidad Autónoma de San Luis Potosí, Departamento de Investigación en Materiales, San Luis Potosí, México.

${ }^{5}$ AIMEN Centro Tecnológico, Departamento de Soldadura, O Porriño, PO, España.

${ }^{6}$ Centro de Investigación y de Estudios Avanzados del IPN, Ramos Arizpe, Coahuila, México.

How to cite: Saldaña-Garcés R, Hernández-García D, García-Vázquez F, Gutiérrez-Castañeda EJ, Verdera D, Deaquino-Lara R. Friction stir welding of dissimilar AA6061-T6 to AZ31B-H24 alloys. Soldagem \& Inspeção. 2020;25:e2525. https://doi.org/10.1590/0104-9224/SI25.25

\begin{abstract}
Friction Stir Welding (FSW) is a solid-state joining process that uses a non-consumable tool to join two facing workpieces without melting the workpiece material. FSW is predominantly used for welding lightweight materials such as aluminum and magnesium alloys. In the present investigation, AA6061-T6 and AZ31B-H24 alloys were joined by FSW using the following parameters: rotational speed of 400, 800, 1200 and $1600 \mathrm{rpm}$, welding speed of 30 and $60 \mathrm{~mm} / \mathrm{min}$ and tilt angle of $1^{\circ}$ and $3^{\circ}$. In some cases, a tool offset of $1 \mathrm{~mm}$ was used into the $\mathrm{Mg}$-based alloy. Microstructural characteristics of the weld joints were analyzed by optical microscopy and scanning electron microscopy. The experimental results show that dissimilar welds can be obtained by placing the AA6061-T6 alloy on the advancing side under two processing conditions: i) without a tool offset using a welding speed of $30 \mathrm{~mm} / \mathrm{min}$, a rotational speed of $400 \mathrm{rpm}$ and a tilt angle of $1^{\circ}(\mathrm{M} 7)$ and ii) with a tool offset and a welding speed of $30 \mathrm{~mm} / \mathrm{min}$, using a rotational speed of $1200 \mathrm{rpm}$ and a tilt angle of $3^{\circ}(\mathrm{M} 3) . \mathrm{Al}_{3} \mathrm{Mg}_{2}$ and $\mathrm{Al}_{12} \mathrm{Mg}_{17}$ intermetallic compounds were observed in the stir zone. Hardness and tensile strength of joints M7 varied from 76 to $129 \mathrm{HV}$, and $88.2 \mathrm{MPa}$ respectively, and these properties varied from 95 to $153 \mathrm{HV}$, and $18.95 \mathrm{MPa}$ in joints M3.
\end{abstract}

Key-words: Friction stir welding (FSW); Dissimilar joints; Aluminum and magnesium alloys.

\section{Soldagem por Fricção de Juntas Dissimilares AA6061-T6/AZ31B-H24}

Resumo: A soldagem por friç̧ão (FSW) é um processo de união em estado sólido que usa uma ferramenta não consumível para unir duas peças de trabalho opostas sem derreter o material da peça. O FSW é usado predominantemente na soldagem de materiais leves, como ligas de alumínio e magnésio. Neste trabalho, ligas AA6061-T6 e AZ31B-H24 foram unidas por FSW variando os seguintes parâmetros: velocidade de rotação $\left(v_{\text {rot }}\right)=400,800,1200$ e $1600 \mathrm{rpm}$, velocidade de deslocamento da ferramenta (vdf) de 30 e $60 \mathrm{~mm} / \mathrm{min}$ e ângulo de inclinação de $1^{\circ}$ e $3^{\circ}$. Em alguns casos, utilizou-se um desvio da ferramenta de $1 \mathrm{~mm}$ em direção à liga de $\mathrm{Mg}$. As características microestruturais das juntas de solda foram analisadas por microscopia óptica e microscopia eletrônica de varredura. Os resultados experimentais mostraram que é possível obter zonas de misturas o soldagem colocando a liga AA6061-T6 no lado do avanço, cumprindo com duas condições de processamento: i) sem inclinação da ferramenta, $v d f=30 \mathrm{~mm} / \mathrm{min}$, $v_{\text {rot }}=400 \mathrm{rpm}$ e um ângulo de inclinação de $1^{\circ}$ (M7) e ii) com desvio da ferramenta e com vdf $=30 \mathrm{~mm} / \mathrm{min}$ e $v_{\text {rot }}=1200 \mathrm{rpm}$ e um ângulo de inclinação de $3^{\circ}\left(\mathrm{M} 3\right.$ ). Foram observados componentes intermetálicos como o $\mathrm{Al}_{3} \mathrm{Mg}_{2}$ e o $\mathrm{Al}_{12} \mathrm{Mg}_{17} \mathrm{na}$ zona de mistura. A dureza e a resistência à tração da solda M7 variou entre 76 e 129 HV, e 88,2 MPa respectivamente, e estas propriedades variaram entre 95 e $153 \mathrm{HV}$, e 18,95 MPa na solda M3.

Palavras-chave: Soldagem por friç̧ão (FSW); Juntas dissimilares; Ligas de alumínio e magnésio.

\section{Introduction}

The ability to produce components from different light alloys and integrate them into the automotive and aerospace industry, is the main technical challenge that places bonding methods as an important part of their manufacture [1,2]. Aluminum (Al) and magnesium (Mg) alloys are increasingly used in these industries because of their low density and high mechanical

Received: 22 Apr., 2020. Accepted: 09 July, 2020.

E-mail: rociogarces1981@gmail.com, rocio.saldana@comimsa.com (RSG)

This is an Open Access article distributed under the terms of the Creative Commons Attribution Non-Commercial License which permits unrestricted non-commercial use, distribution, and reproduction in any medium provided the original work is properly cited. 
strength [2-4], however, the use of conventional fusion welding processes leads to the formation of intermetallic compounds (IMC) in the melting zone, generating high hardness and low ductility in the joints $[5,6]$.

Friction stir welding (FSW) is a solid-state process that avoids problems related to solidification such as porosity, solute redistribution and cracking [4,7]. However, the final microstructural and mechanical properties of welded dissimilar joints depends strongly on the process parameters of FSW. Some authors have reported the presence of $\mathrm{Al}_{3} \mathrm{Mg}_{2}$ and $\mathrm{Al}_{12} \mathrm{Mg}_{17}$ compounds in the welding zone of $\mathrm{Al} / \mathrm{Mg}$ dissimilar joints, which negatively affect their mechanical properties [1,8-21].

Dorbane et al. [1] welded $3 \mathrm{~mm}$-thick plates of AA6061-T6 and AZ31B alloys, obtaining good-quality joints by placing the Al alloy on the advancing side, using a rotational speed of $1400 \mathrm{rpm}$ and $500 \mathrm{~mm} / \mathrm{min}$ of welding speed. Firouzdor and Kou [8] welded $1.6 \mathrm{~mm}$-thick plates of AA6061-T6 and AZ31B-H24 alloys, varying the rotational and welding speed from 1000 to $2200 \mathrm{rpm}$, and from 38 to $305 \mathrm{~mm} / \mathrm{min}$, respectively. In addition, the used a tool offset of $1.5 \mathrm{~mm}$ in the Al or Mg alloy with a H13 steel tool. A reduction of IMC in the joint was observed when the AZ31B-H24 alloy was placed on the advancing side, for low welding speed and high rotational speed. This behavior was related to low heat generation and an increase of the weld resistance, when using a tool offset on the side of the magnesium alloy.

Fu et al. [9] welded 3 mm-thick plates of AA6061-T6 and AZ31B-O alloys, obtaining sound joints using intermediate rotational speeds $(600-800 \mathrm{rpm})$, low welding speeds $(30-61 \mathrm{~mm} / \mathrm{min}$ ) and placing the $\mathrm{Mg}$ in the advancing side, with a tool offset of $0.3 \mathrm{~mm}$ into Mg-based alloy. Malarvizhi and Balasubramanian [14] welded $6 \mathrm{~mm}$-thick plates of AA6061-T6 and AZ31B-O to investigate the effect of the shoulder diameter, varied from 12 to $24 \mathrm{~mm}$. These authors used $400 \mathrm{rpm}$ of rotational speed, $19.8 \mathrm{~mm} / \mathrm{min}$ of welding speed and $12 \mathrm{kN}$ of axial force, placing the $\mathrm{Mg}$ in the advancing side. A tensile strength of $192 \mathrm{MPa}$ and a defect-free joint were obtained with a diameter of $21 \mathrm{~mm}$.

As described above, there is a strong influence of the FSW process parameters on the quality, microstructural and mechanical properties of welded joints.

The tool rotational speed is one most important parameter that may influence the microstructure and properties of friction stir welded joints. Heat generated increases with increasing tool rotation speed. It has been reported that low tool rotational speeds lead to grain refinement promoting an increase in the mechanical properties of stir welded joints. It is also vital to identify the advancing side and the retreating side of the joint since this arrangement influence the flow of materials and thus affecting the weld strength. A proper mix and suitable flow of materials result in an appropriate bonding between welded materials. In contrast, a non-uniform material flow result in creation of defects such as voids and tunnels, due to weak and improper mixing and flow of materials. Therefore, the aim of this research is to investigate the microstructural changes and mechanical behavior of dissimilar aluminum AA6061-T6 and magnesium AZ31B-H24 alloys joined by FSW process.

\section{Methodology}

Plates of AA6061-T6 and AZ31B-H24 alloys with dimensions of $150 \mathrm{~mm}$ long $\times 60 \mathrm{~mm}$ wide $\times 6 \mathrm{~mm}$ thick were used to investigate the effects of FSW process parameters on the quality, microstructural and mechanical properties of the joints. Chemical composition of AA6061-T6 alloy was determined by optical emission spectrometry (OES) using a PMI-MASTER PRO optical emission spectrometer, while the composition of AZ31B-H24 alloy was determined by inductively coupled plasma (ICP) using a Thermo Scientific ICAP 6500 DUE spectrometer.

The plates of AA6061-T6 and AZ31B-H24 alloys were welded in the butt joint configuration, using a STIR PDS Intelligent Stir Welding MTS machine. The FSW tool (the only one available for these experiments) with a shoulder diameter of $20 \mathrm{~mm}$ and concave shoulder of $7^{\circ}$ was made of $\mathrm{H} 13$ steel, while the pin with dimensions of $5.59 \mathrm{~mm}$ height and $5.08 \mathrm{~mm}$ diameter was made of a MP159 nickel-cobalt based alloy (Figure 1). The parameters used for the welds are enlisted in Table 1. In this investigation, force was not considered as a parameter because it was working in position control and when this is the case, the force in $\mathrm{Z}$ is one of the results of the process, not a parameter to be varied.

Variations in the workpiece position in the side of $\mathrm{Mg}$ alloy, and the tool inclination angle (penetrating slightly the shoulder of plates during welding), were conducted to promote a uniform material flow.

Table 1. Parameters of the FSW process.

\begin{tabular}{ccccccc}
\hline \multirow{2}{*}{ Specimens } & $\begin{array}{c}\text { Rotational } \\
\text { speed } \boldsymbol{w}(\mathbf{r p m})\end{array}$ & $\begin{array}{c}\text { Welding speed } \boldsymbol{v} \\
(\mathbf{m m} / \mathbf{m i n})\end{array}$ & $\begin{array}{c}\text { Tool offset } \\
\text { into } \mathbf{M g}(\mathbf{m m})\end{array}$ & \multicolumn{2}{c}{ Material position $^{\mathrm{a}}$} & Tilt \\
\cline { 4 - 6 } M1 & 1600 & 30 & 1 & AZ & RS & $1^{\circ}$ \\
M2 & 1600 & 60 & 0 & AA60661-T6 & AZ31B-H24 \\
M3 & 1200 & 30 & 1 & AA6061-T6 & AZ31B-H24 & $3^{\circ}$ \\
M4 & 1200 & 60 & 0 & AZ31B-H24 & AA6061-T6 & $1^{\circ}$ \\
M5 & 800 & 30 & 0 & AZ31B-H24 & AA6061-T6 & $3^{\circ}$ \\
M6 & 800 & 60 & 1 & AA6061-T6 & AZ31B-H24 & $1^{\circ}$ \\
M7 & 400 & 30 & 0 & AA6061-T6 & AZ31B-H24 & $1^{\circ}$ \\
M8 & 400 & 60 & 1 & AZ31B-H24 & AA6061-T6 & $3^{\circ}$ \\
\hline
\end{tabular}

aS: Advancing side; RS: Retreating side. 


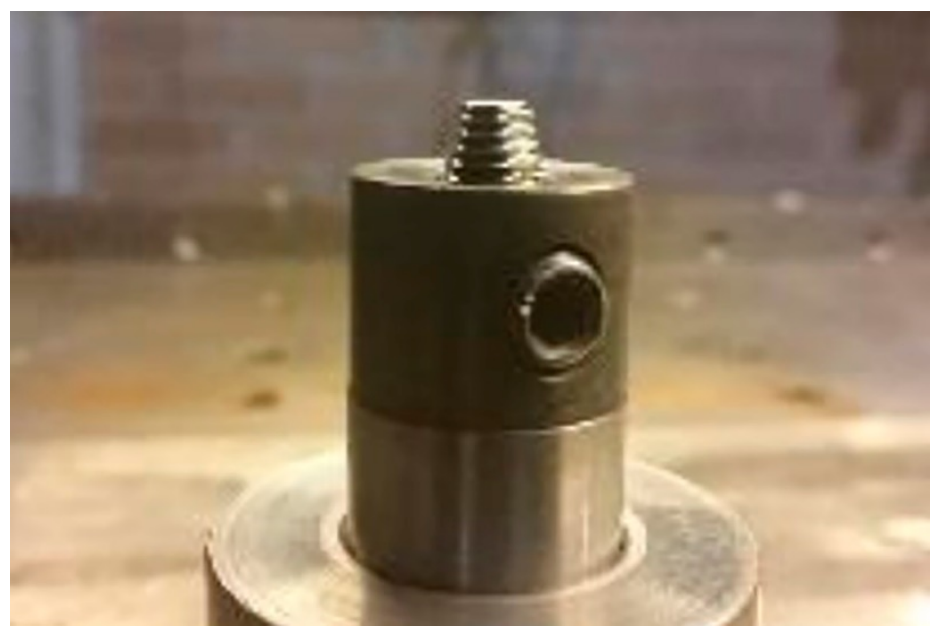

Figure 1. FSW tool used in this study.

The cross-section of welds was prepared by conventional metallographic procedures: grinding, polishing and etching. First the etching was carried out using Keller's $\left(2 \mathrm{~mL} \mathrm{HF}, 3 \mathrm{~mL} \mathrm{HCl}, 5 \mathrm{~mL} \mathrm{HNO}\right.$ and $190 \mathrm{~mL} \mathrm{H}_{2} \mathrm{O}$ ) to reveal the microstructure of the aluminum alloy and stir zone, and then to be analyze. After aluminum, with a mixture of $10 \mathrm{~mL}$ acetic acid, $10 \mathrm{~mL}$ distilled water and $4.2 \mathrm{~g}$ picric acid in $100 \mathrm{~mL}$ ethanol to reveal the microstructure of the magnesium alloy.

The macro-and microstructural characterization were carried out using a Nikon SMZ 7457 stereoscope and a Nikon Eclipse MA optical microscope, respectively. The local chemical composition of the intermetallic compounds was obtained by scanning electron microscopy (SEM) using a Phillips XL30 microscope equipped with an energy dispersive (EDS) detector. Additionally, the stir zone was analyzed by X-ray diffraction (XRD) in a Rigaku DMAX-2200 diffractometer using Cu Ka $(\lambda=0.154 \mathrm{~nm})$ radiation.

Uniaxial tension test were conducted according to specifications of standard ASTM E8 in a MTS QTEST/100 universal machine, testing two specimens each. Microhardness profiles were performed in different weld zones and base metal in a TUK 2500 microhardness tester with a $0.3 \mathrm{~kg}_{\mathrm{f}}$ load according to procedures of ASTM E384.

\section{Results and Discussion}

\subsection{Chemical composition and microstructure of the as-received alloys}

Chemical compositions and mechanical properties of alloys in their as-received conditions are shown in Table 2. Regarding tensile tests, duplicate experiments were carried out for each alloy reporting the average value. The reported microhardness average value of each alloy was obtained from 10 indentations, considering a separation between indentations of 2.5 times the diameter of the indentation.

Table 2. Chemical compositions and mechanical properties of base metals (wt. \%).

\begin{tabular}{|c|c|c|c|c|c|c|c|c|c|}
\hline \multicolumn{10}{|c|}{ Chemical composition (wt. \%) } \\
\hline & Al & Mg & $\mathbf{S i}$ & $\mathbf{F e}$ & $\mathrm{Cu}$ & Mn & $\mathbf{Z n}$ & $\mathrm{Cr}$ & $\mathbf{T i}$ \\
\hline AA6061-T6 & Bal. & 0.928 & 0.593 & 0.497 & 0.237 & 0.152 & 0.047 & 0.139 & 0.09 \\
\hline AZ31B-H24 & 2.55 & Bal. & 0.008 & 0.041 & 0.002 & 0.31 & 0.79 & - & - \\
\hline \multicolumn{10}{|c|}{ Mechanical properties } \\
\hline & \multicolumn{2}{|c|}{$\begin{array}{c}\text { Tensile strength } \\
\text { (MPa) }\end{array}$} & \multicolumn{2}{|c|}{ Elongation (\%) } & \multicolumn{2}{|c|}{ Modulus (MPa) } & \multicolumn{3}{|c|}{ Microhardness $\left(\mathrm{HV}_{0.3}\right)$} \\
\hline AA6061-T6 & \multicolumn{2}{|c|}{324.6} & \multicolumn{2}{|c|}{16.66} & \multicolumn{2}{|c|}{57624} & \multicolumn{3}{|c|}{113 (average) } \\
\hline AZ31B-H24 & \multicolumn{2}{|c|}{274.2} & \multicolumn{2}{|c|}{16.48} & \multicolumn{2}{|c|}{38266.045} & \multicolumn{3}{|c|}{67 (average) } \\
\hline
\end{tabular}

Figure 2 shows the microstructure of the as-received alloys, to reveal the microstructure of the aluminum alloy, etching was carried out using Keller's ( $2 \mathrm{~mL} \mathrm{HF}, 3 \mathrm{~mL} \mathrm{HCl}, 5 \mathrm{~mL} \mathrm{HNO}_{3}$ and $190 \mathrm{~mL} \mathrm{H}_{2} \mathrm{O}$ ) and to reveal the microstructure of the magnesium alloy, a mixture of $10 \mathrm{~mL}$ acetic acid, $10 \mathrm{ml}$ distilled water and $4.2 \mathrm{~g}$ picric acid in $100 \mathrm{~mL}$ ethanol. As can be observed, the AA6061 alloy in the T6 condition exhibits large grains with equiaxial shape and the presence of $\mathrm{Mg}_{2} \mathrm{Si}$ precipitates (Figure $2 \mathrm{a}$ ). Microanalyses obtained by SEM-EDS (Figure 2c) show the presence of particles rich in Al-Fe-Si and Mg-Si, which are uniformly 
distributed in the matrix (Figure $2 \mathrm{~b}$ ). Although their stochiometric is not presented in the present work, some authors have related them with the presence of intermetallic compounds of AlFeSi and $\mathrm{Mg}_{2} \mathrm{Si}$ [1] (Figure 2b).
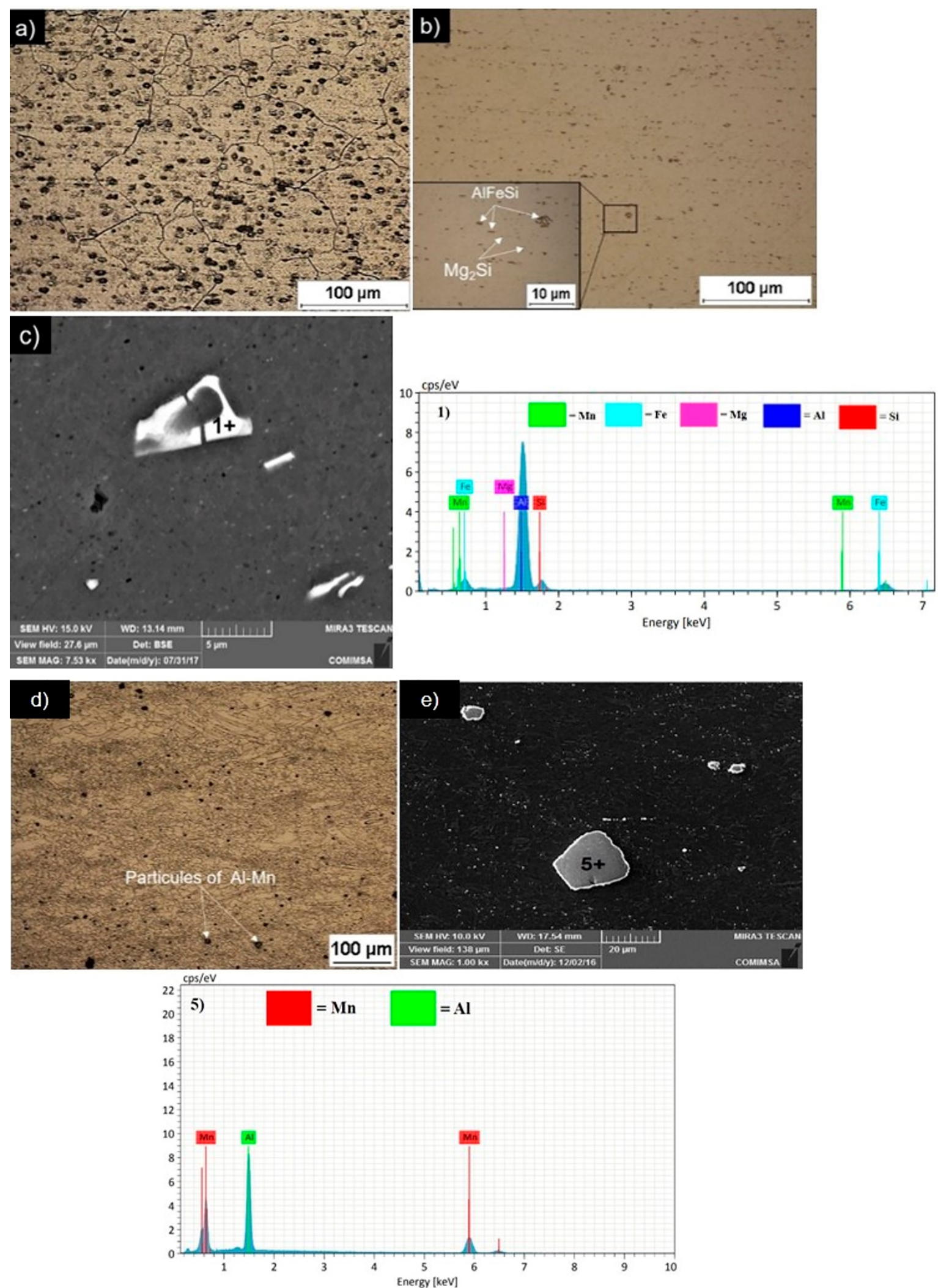

Figure 2. Base metals: AA6061-T6 ((a) large grains with equiaxial shape; (b) AlFeSi and Mg ${ }_{2}$ Si particles; (c) punctual analysis by MEB-EDS) and AZ31B-H24 ((d) small equiaxed grains; (e) presence of Al-Mn particles and punctual analysis by MEB-EDS). 
The microstructure of the AZ31B-H24 alloy is characterized by the presence of small equiaxed grains, deformed grans with different sizes and the presence of Al-Mn particles (Figure 2e). The heterogeneity in the grain structure can be related either to a non-homogeneous plastic deformation in the steel plate due to a non-uniform grain size prior to steel rolling, or to an incomplete recrystallization by partial annealing (H24 condition) [22].

\subsection{Welding defects}

Table 3 shows the surface appearance and characteristics of dissimilar joints of $\mathrm{Al} / \mathrm{Mg}$ after the FSW process. The joint of AA6061-T6/AZ31B-H24 alloys was obtained placing the Al alloy on the advancing side, using a welding speed of $30 \mathrm{~mm} / \mathrm{min}$, rotational speed of $1200 \mathrm{rpm}$, tilt angle of $3^{\circ}$ and tool offset into $\mathrm{Mg}$ alloy $(1 \mathrm{~mm})$ to $\mathrm{M} 3$ and a welding speed of $30 \mathrm{~mm} / \mathrm{min}$, rotational speed of $400 \mathrm{rpm}$, tilt angle of $1^{\circ}$ and without tool offset to $\mathrm{M7}$.

Table 3. Surface appearance of welds by FSW of alloys AA6061-T6/AZ31B-H24.

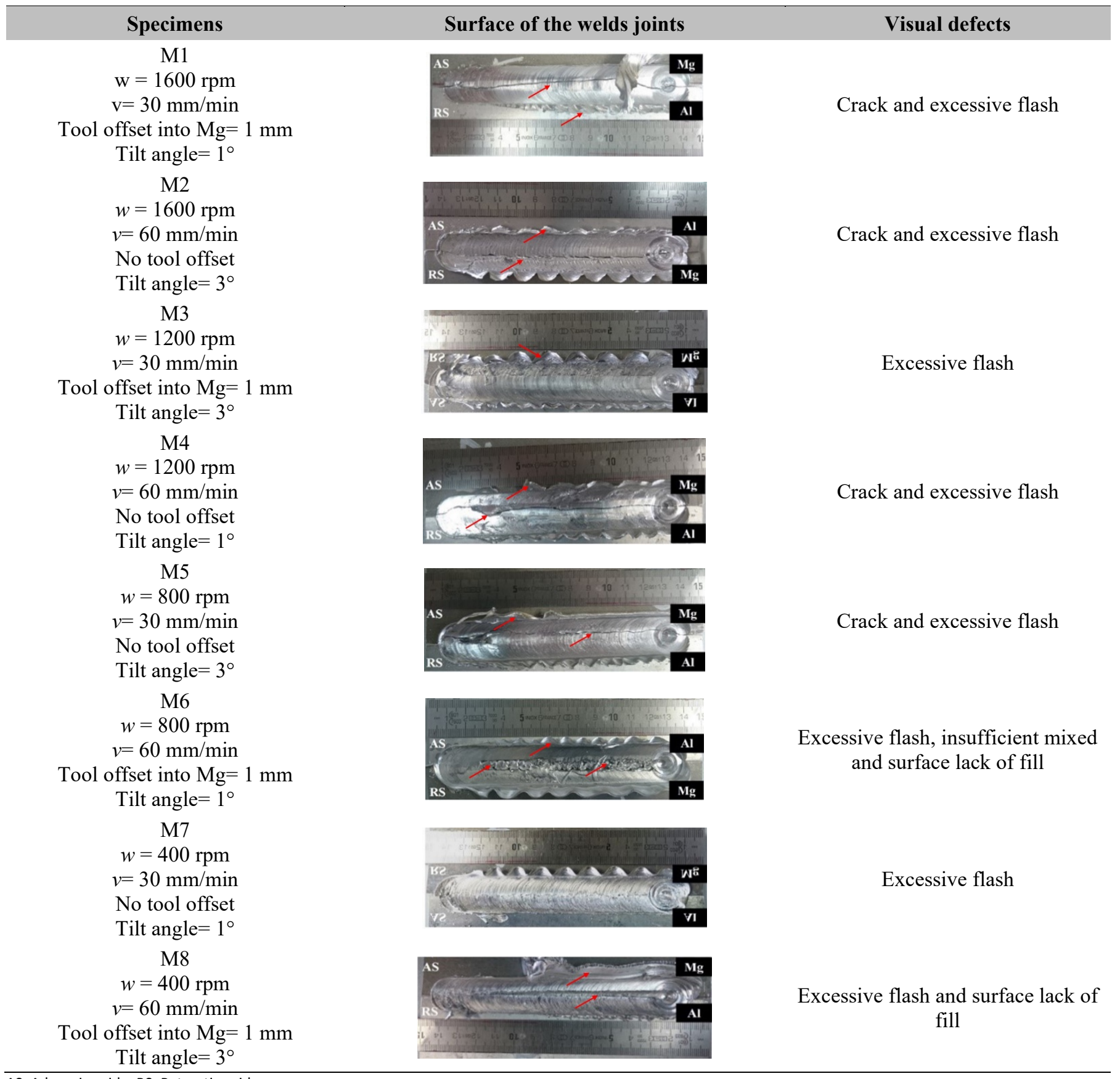


However, most dissimilar joints were fractured because of the presence of defects such as lack of fill, insufficient mixed or formation of intermetallic compounds, resulting in the formation of cracks along the weld. In contrast, when using the Mg alloy on the advancing side of the joint of these materials, the defects are not observed, which is an opposite behavior to the one obtained in other studies [9]. This result suggests that when placing the Al alloy on the retreating side, aluminum is not able to deform enough to be blended with the Mg alloy, which can be explained by the less deformation of the material on the retreating side.

\subsection{Macro and microstructure}

Figures 3 and 4 show the macro and microstructural features of joints M3 and M7, respectively. It is clearly observed in both cases that there is a lack of penetration, which can be attributed to the fact that the pin height is smaller than the thickness of the plates.
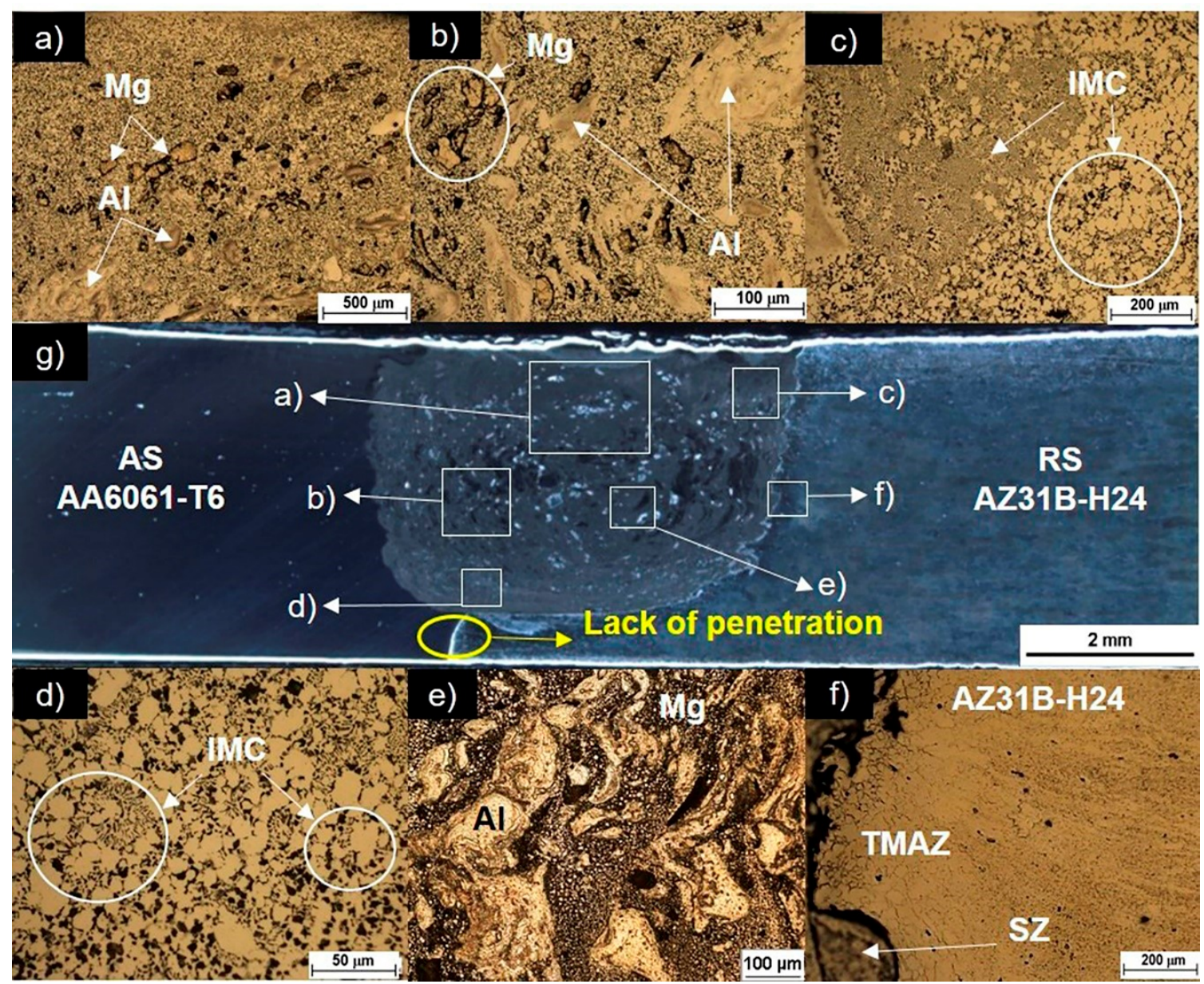

Figure 3. Cross-sections showing different areas of $M 3$ joint with $w=1200 \mathrm{rpm}, v=30 \mathrm{~mm} / \mathrm{min}, 1 \mathrm{~mm}$ of tool offset and tilt angle of $3^{\circ}$. The central image $(\mathrm{g})$ shows the welding and the different areas considered for the analysis (a-f) and that are observed at higher magnifications around it. AZ31B-H24 (right) and AA60601-T6 (left): retreating side (RS) and advancing side (AS), respectively. The lack of penetration defect is indicated in Figure 3g. (IMC: intermetallic compounds; TMAZ: thermomechanically affected zone; SZ: stir zone). 


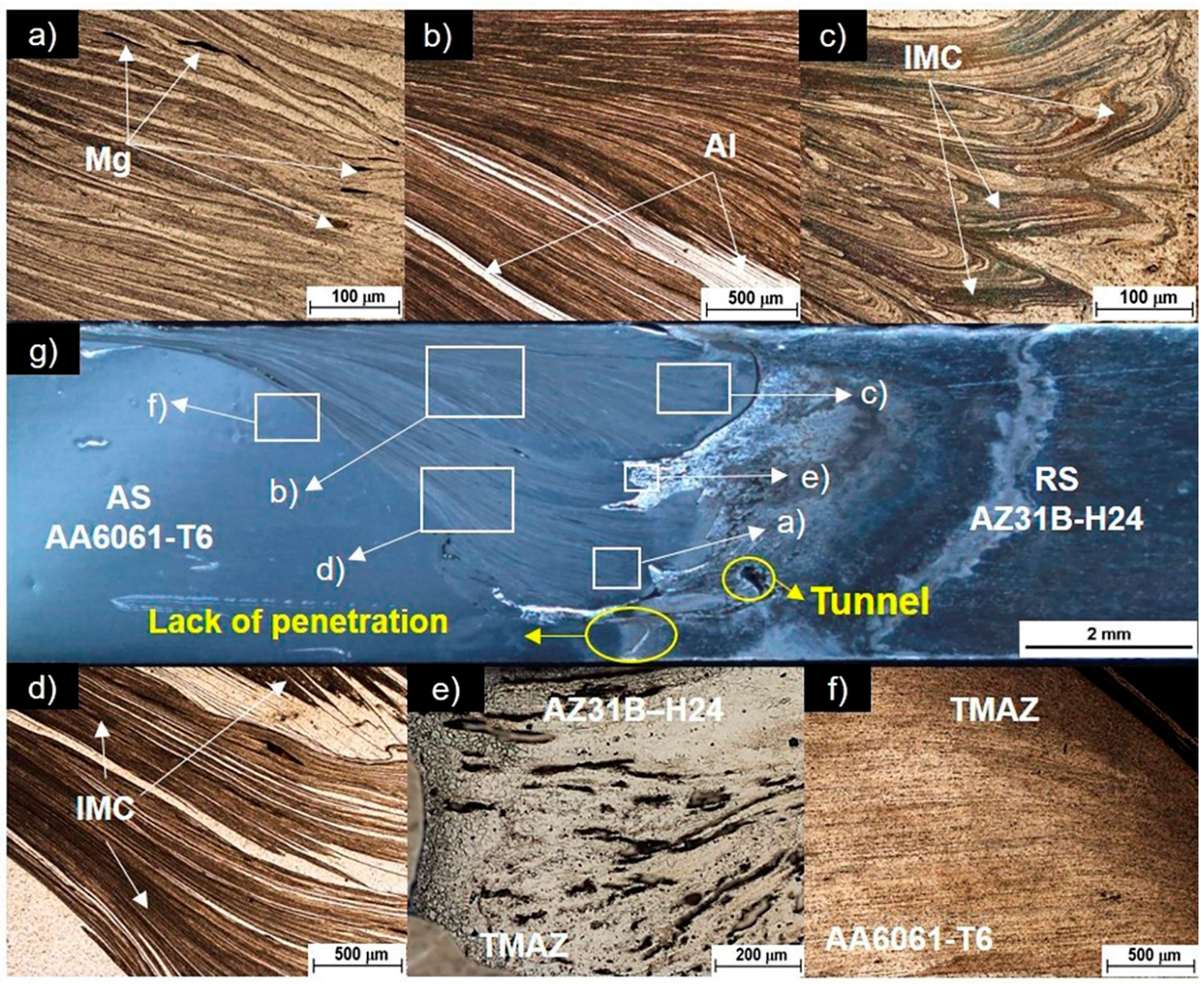

Figure 4. Cross-section of different areas of $M 7$ joint with $w=400 \mathrm{rpm}, v=30 \mathrm{~mm} / \mathrm{min}$, no tool offset and tilt angle of $1^{\circ}$. The central image $(\mathrm{g})$ illustrates the welding and the different sections for the analysis (a-f) and that are observed at higher magnifications around it. AZ31B-H24 (right) and AA60601-T6 (left): retreating side (RS) and advancing side (AZ), respectively. The lack of penetration and tunnel defects are indicated in Figure 4g. (IMC: intermetallic compounds; TMAZ: thermomechanically affected zone).

In the case of the M7 joint, it is observed the well-known "tunnel" defect, which is common in the FSW process and has a detrimental effect on the mechanical properties of the welds. This defect is observed in the retreating side (AZ31B-H24) of the joints welded with the lowest rotational speed (400rpm). Apparently, it causes insufficient plasticization of the materials welded and imbalance in the material movement around the pin. Khan et al. [23] performed dissimilar welds of AA5083-H116/AA6063-T6 by FSW; it was found that the "tunnel" defect may be present in dissimilar aluminum joints by: (1) inappropriate choice of tool offset and (2) inadequate penetration of the pin, causing a lower heat generation, making the material flow during the welding process difficult. Otherwise, the main difference between these joints is the mixing of the materials.

A complete mixture of the materials having a more homogeneous stir zone (SZ) is observed in welds with higher rotational speed (compare Figure 3g with Figure $4 \mathrm{~g}$ ). The microstructure is characterized by complex flow patterns consisting on lamellar-like shear bands of $\mathrm{Al}$ and $\mathrm{Mg}$ alloy that repeat intermittently, which have been previously observed in the other dissimilar joints of $\mathrm{Al} / \mathrm{Mg}$ by FSW $[9-12,14,19]$. This intercalated laminar structure is caused by three factors: (1) incorporation of material by the thread of tool pin at each rotation [9,24]; (2) the severe deformation during the FSW process; and (3) the different deformability of $\mathrm{Al}$ and $\mathrm{Mg}$. The presence of $\mathrm{Al}$ and $\mathrm{Mg}$ dispersed material in the $\mathrm{SZ}$ is also observed in both dissimilar joints (see Figures $3 a, 3 b, 4 a$ and $4 b$ ).

The formation of intermetallic compounds (IMC) of $\mathrm{Al}_{3} \mathrm{Mg}_{2}$ and $\mathrm{Al}_{12} \mathrm{Mg}_{17}$ during the FSW process of dissimilar joints of $\mathrm{Al} / \mathrm{Mg}$ has been reported in other studies $[1,8,9,11,12,15,17,20]$. As observed in Figure 3c, islands of a globular phase and a typical eutectic structure are observed in the SZ of the M3 weld.

This globular morphology is very similar to the one of the $\mathrm{Al}_{12} \mathrm{Mg}_{17}$ phase observed during lap joint of AA6061/AZ31 alloys by FSW, besides the eutectic structure is similar to $\mathrm{Mg}+\mathrm{Al}_{12} \mathrm{Mg}_{17}$ phase reported elsewhere [11,12]. Additionally, this dissimilar joint has a higher Mg content considering that the dark areas in the microstructure of the aluminum alloy in the SZ, correspond to magnesium material and Mg-rich phases (Figure 3e). Regev et al. [17] mention that the chemical reaction and diffusion between the AZ31 and AA6061 alloys leads to the formation of fine lamellae of intermetallic compounds in FSW welding. According to the above mentioned, it is suggested that IMC's are formed in the intercalated Al-Mg structure of the M7 joint (Figures 4c, 4d) as reported in other studies of dissimilar joints $[16,17,19]$.

It has been also reported that grain refinement in the SZ of welds of $\mathrm{Al} / \mathrm{Mg}$ by FSW process can occur due to the severe plastic deformation caused by the tool pin and heat generation produced by the friction between the material and the tool shoulder $[1,10,13]$. Although grain size was not measured in SZ, it can be clearly observed that it is smaller in the 
thermomechanically affected zone (TMAZ) on the magnesium side with granulometry varying between 8.5 and 9 ASTM grain size.

\subsection{Scanning electron microscopy and X-ray diffraction}

Figure 5 shows the results obtained by scanning electron microscopy using energy dispersive X-ray dispersive analysis (SEM-EDS) to obtain the elemental analysis and chemical characterization in joint $\mathrm{M} 3$. As can be seen, there is a higher Mg content in the stir zone as well as dispersed phases like Al-Mn particles (Figure 5a) and $\alpha$-AlFeSi (Figures 5b, 5e), which is consisting with the results of chemical analysis shown in Table 4 . The darkkest areas correspond to $\mathrm{Mg}$-rich phases $\left(\mathrm{Al}_{12} \mathrm{Mg}_{17}\right)$, while those whose tone is more tenuous to $\mathrm{Al}\left(\mathrm{Al}_{3} \mathrm{Mg}_{2}\right)$ phase. Sato et al. [18] reported that during dissimilar metal joining of AA1050 to AZ31 alloys by FSW process, there is the formation of a constitutional liquation. For instance, liquid phase that may appear as a result of a mutual diffusion between the $\mathrm{Al}$ and $\mathrm{Mg}$ atoms, when the material is constantly maintained near the melting temperature. After solidification, during the cooling cycle of $\mathrm{FSW}, \mathrm{Al}_{12} \mathrm{M}_{17}$ was observed. Figure 5 a shows an eutectic structure composed mainly of $\mathrm{Mg}+\mathrm{Al}_{12} \mathrm{Mg}_{17}$, which has a composition of 66.49 wt. \% $\mathrm{Mg}$ and 33.51 wt. \% Al.

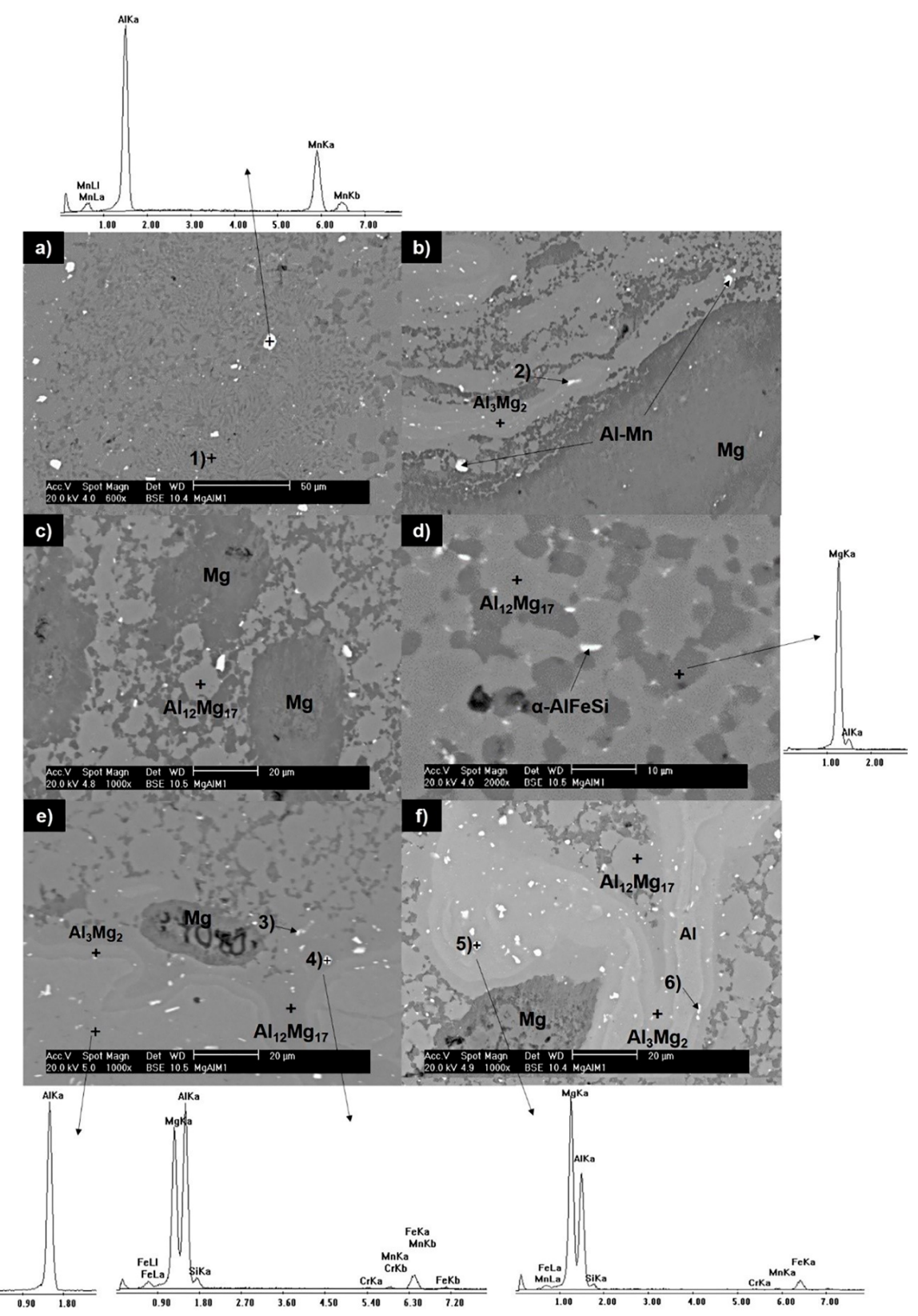

Figure 5. SEM-EDS analysis of phases such $\mathrm{Al}_{3} \mathrm{Mg}_{2}, \mathrm{Al}_{12} \mathrm{Mg}_{17}$ y $\alpha$-AlFeSi present in different sections (a-f) in SZ of joint $\mathrm{M3}$ (1200 rpm, $30 \mathrm{~mm} / \mathrm{min}$, tool offset of $1 \mathrm{~mm}$ and tilt angle of $3^{\circ}$ ). (The numbers from 1 to 6 correspond to the analysis of different particles and their chemical composition is shown in Table 4). 
It is also possible to observe in Figures $5 \mathrm{c}$ and $5 \mathrm{~d}$ the presence Al12Mg17 intermetallic compound with a globular morphology, which is surrounded by Mg according EDS analysis. These results are very similar to those reported in other studies for $\mathrm{Al} / \mathrm{Mg}$ joints $[1,11,12]$. On the other hand, small clusters of Al-rich compound (Al3Mg2) were presented close to the interface between $\mathrm{Mg}$ alloy and stir zone (Figure $5 \mathrm{~b}$ ). This intermetallic is present as a layer between Al and Al12Mg17 phase according to results obtained by EDS analysis. In addition, bright white colored particles whose chemical composition is similar to Al3Mg2 and Al12M17 (Table 4) are also observed in the microstructure (Figures 5e and 5f).

Table 4. Chemical composition (wt.\%) obtained by EDS in joint M3 from regions shown in Figure 5.

\begin{tabular}{|c|c|c|c|c|c|c|c|}
\hline $\begin{array}{l}\text { Zone presented in } \\
\text { Figure } 5\end{array}$ & Al & Mg & Si & $\mathbf{F e}$ & Mn & $\mathrm{Cr}$ & Phase \\
\hline 1 & 33.51 & 66.49 & - & - & - & - & $\mathrm{Mg}+\mathrm{Al}_{12} \mathrm{Mg}_{17}$ \\
\hline 2 & 68.13 & 1.59 & 6.89 & 17.92 & 2.67 & 2.79 & $\alpha-\mathrm{AlFeSi}$ \\
\hline 3 & 70.64 & - & 6.6 & 19.79 & 1.86 & 1.11 & $\alpha-\mathrm{AlFeSi}$ \\
\hline 4 & 59.78 & 33.75 & 1.43 & 2.58 & 1.56 & 0.89 & $\mathrm{Al}_{3} \mathrm{Mg}_{2}$ \\
\hline 5 & 45.03 & 51.03 & 0.91 & 1.93 & 0.4 & 0.69 & $\mathrm{Al}_{12} \mathrm{Mg}_{17}$ \\
\hline 6 & 58.25 & 32.45 & - & 4.2 & 5.1 & - & $\mathrm{Al}_{3} \mathrm{Mg}_{2}$ \\
\hline
\end{tabular}

The microstructure of joint M7 (lower rotational speed), exhibits dispersed phases in SZ that come from the base metals, which correspond to iron-rich phases such as $\alpha$-AlFeSi (Figure 6a). This observation is supported by the results of chemical analysis shown in Table 5.

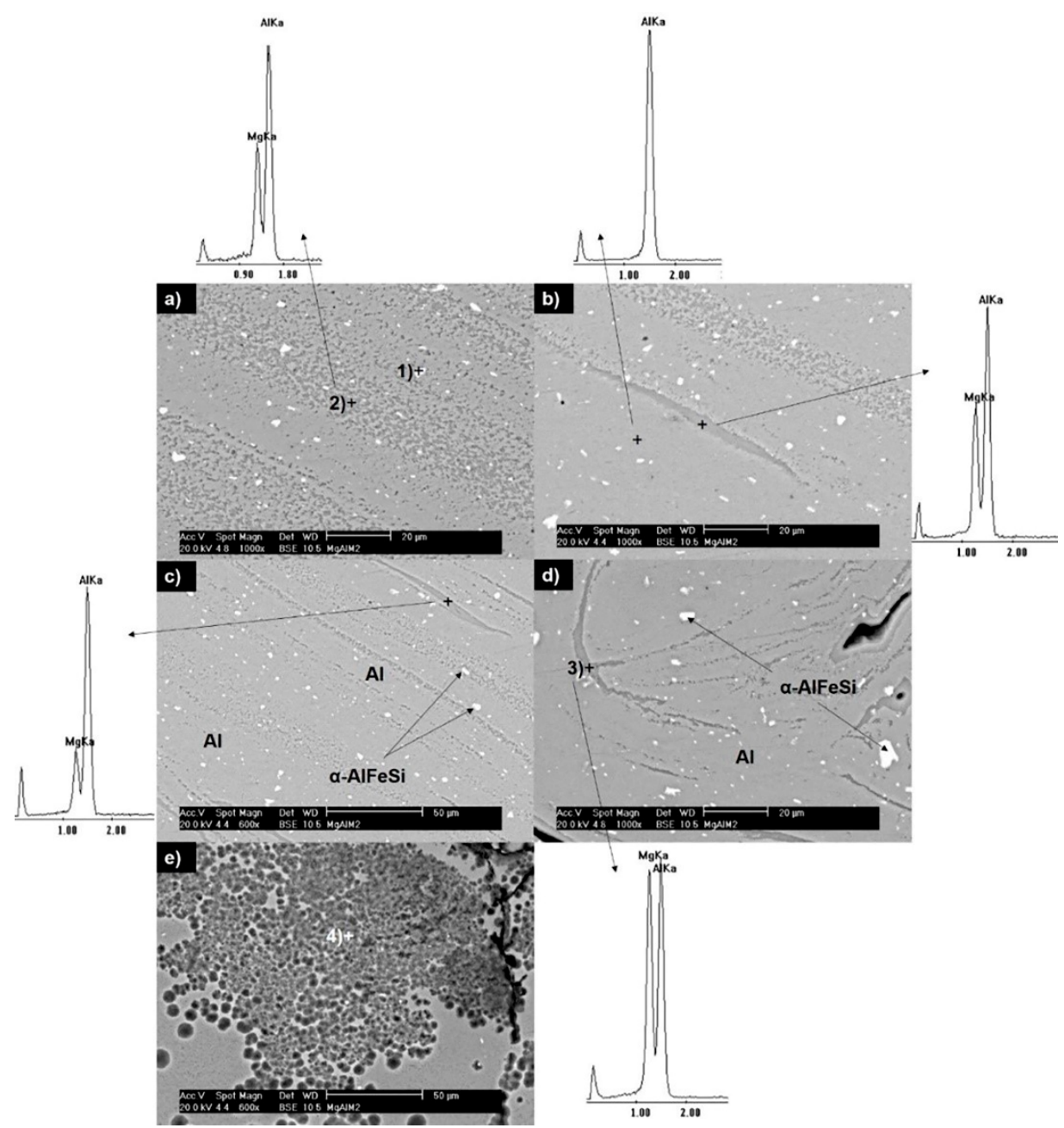

Figure 6. SEM-EDS analysis of phases such $\alpha$-AIFeSi and base metal particles present in different sections (a-e) in SZ of joint M7 (400rpm, $30 \mathrm{~mm} / \mathrm{min}$, without tool offset of $\mathrm{Mg}$ side and tilt angle of $1^{\circ}$ ). (The numbers from 1 to 4 correspond to the analysis of different particles and their chemical composition is shown in Table 5). 
Table 5. Chemical composition (wt.\%) obtained by EDS in joint M7 from regions shown in Figure 6.

\begin{tabular}{ccccccccc}
\hline $\begin{array}{c}\text { Zone presented in } \\
\text { Figure 6 }\end{array}$ & Al & Mg & Si & Fe & Mn & Cr & Phase \\
1 & 74.95 & 3.94 & 6.52 & 13.34 & 1.25 & - & $\alpha-\mathrm{AlFeSi}$ \\
2 & 59.1 & 11.59 & 6.89 & 16.92 & 2.67 & 2.79 & $\mathrm{Al}_{3} \mathrm{Mg}_{2}$ \\
3 & 61.36 & 36.18 & - & - & 1.56 & 0.89 & $\mathrm{Al}_{3} \mathrm{Mg}_{2}$ \\
4 & - & 91.14 & - & 8.85 & - & - & $\mathrm{Mg}$ \\
\hline
\end{tabular}

The typical solidification microstructure is not observed in this weld. The formation of IMC in SZ relates to a constitutional liquation during welding under a strong shear effect during solidification [16]. Shi et al. [19] reported the formation of intermetallic compounds with lamellar structure in dissimilar joints of A6061-T6/Mg (lab-prepared Mg alloy) by FSW, attributing their formation to the presence of constitutional liquation during welding. In the case of joint $\mathrm{M7}$, there are observed some bands that correspond to the $\mathrm{Al}_{3} \mathrm{Mg}_{2}$ intermetallic compound (Figures 6a-d), which is supported by semi-quantitative EDS analysis presented in Table 5 .

The presence of these IMC can be attributed to the existence of a higher content of Al in the stir zone because no tool offset was used into the Mg alloy during the process. In addition, some Mg-rich areas are observed in Figure 6e, which suggests an insufficient mixing during the welding process.

Figure 7 shows the XRD patterns obtained in the $\mathrm{SZ}$ of AA6061-T6/AZ31B-H24 dissimilar welds. As can be seen, $\mathrm{Al}_{12} \mathrm{Mg}_{17}$ and $\mathrm{Al}_{3} \mathrm{Mg}_{2}$ compounds are observed in the welds. The presence of these intermetallics suggests that temperature during welding was higher than $450^{\circ} \mathrm{C}$, and thus superior to the eutectic points: $\mathrm{Mg}+\mathrm{Al}_{12} \mathrm{Mg}_{17}\left(437^{\circ} \mathrm{C}\right)$ and $\mathrm{Al}+\mathrm{Al}_{3} \mathrm{Mg} 2\left(450^{\circ} \mathrm{C}\right)$, according to the binary Al-Mg [25].
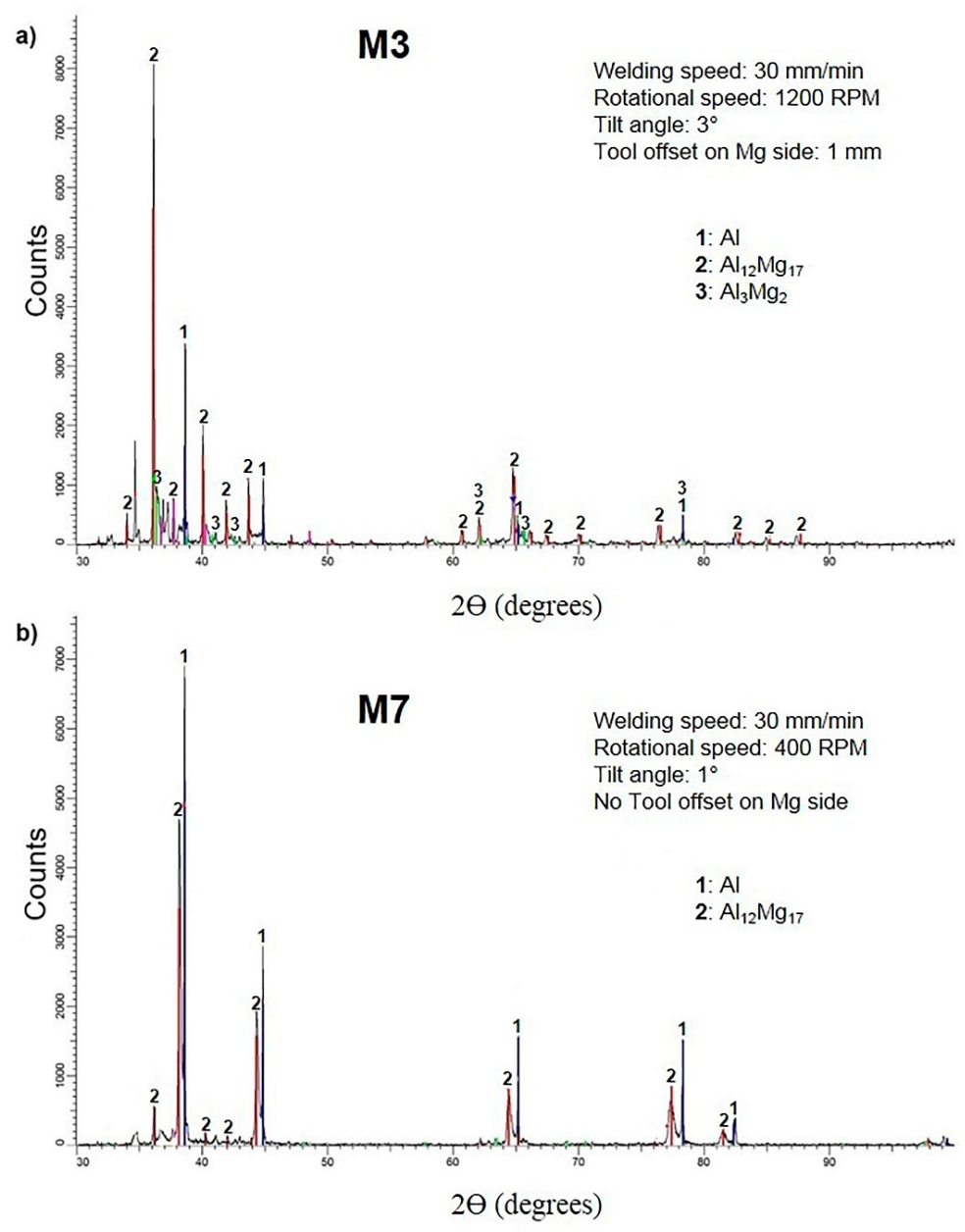

Figure 7. XRD patterns corresponding to SZ of joints: (a) M3; and (b) M7. 
In the case of joint M7 (Figure 7b) which was welded with a lower rotation speed (400 RPM), only the intermetallic $\mathrm{Al}_{12} \mathrm{Mg}_{17}$ is observed by this technique, which could be attributed to a lower heat generation in this weld.

\subsection{Microhardness}

Figures 8 and 9 show the microhardness profiles, obtained in cross sections, from the central part of dissimilar joints. It is important to mention that to identify the different zones of the joints, the samples had to be chemically etching as mentioned previously in the methodology. Subsequently, measurements were made to take them as a reference when performing the microhardness profiles (The welds shown in the microhardness graphs, only serve as a reference to the center of the joint, not to show the different zones). Three microhardness profiles were obtained in different regions of each sample: superior, central and inferior. The one obtained in the central region is presented in this work, but worthy to mention is that the other two profiles were very similar. An increase of microhardness in the SZ of both welds is observed (higher than $150 \mathrm{HV}$ and $130 \mathrm{HV}$ in samples $M 3$ and M7, respectively), which agrees with results reported by other authors $[1,11,12,16,17,26]$. Two factors can be related to this behavior: (1) grain refinement as a results of severe plastic deformation and (2) the formation of IMC $\left(\mathrm{Al}_{3} \mathrm{Mg}_{2}\right.$ and $\left.\mathrm{Al}_{12} \mathrm{Mg}_{17}\right)$ in the SZ [1].

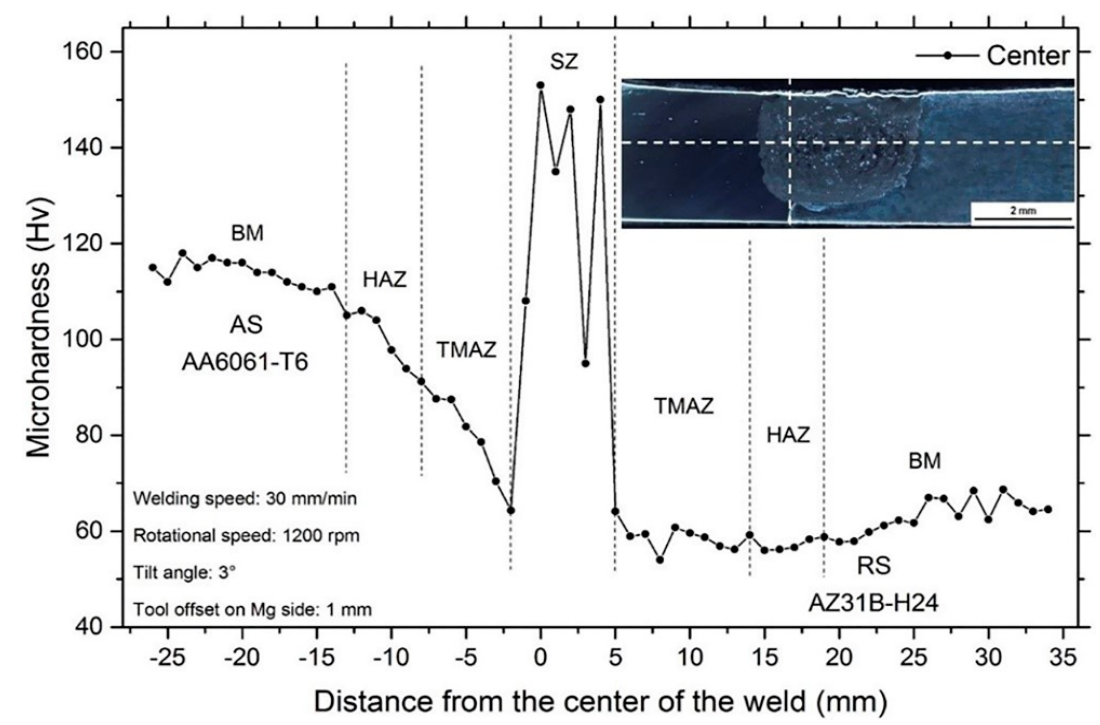

Figure 8. Microhardness profile in joint M3. (BM: base metal; HAZ: heat affected zone; TMAZ: thermomechanically affected zone; SZ: stir zone; AS: advancing side; RS: retreating side).

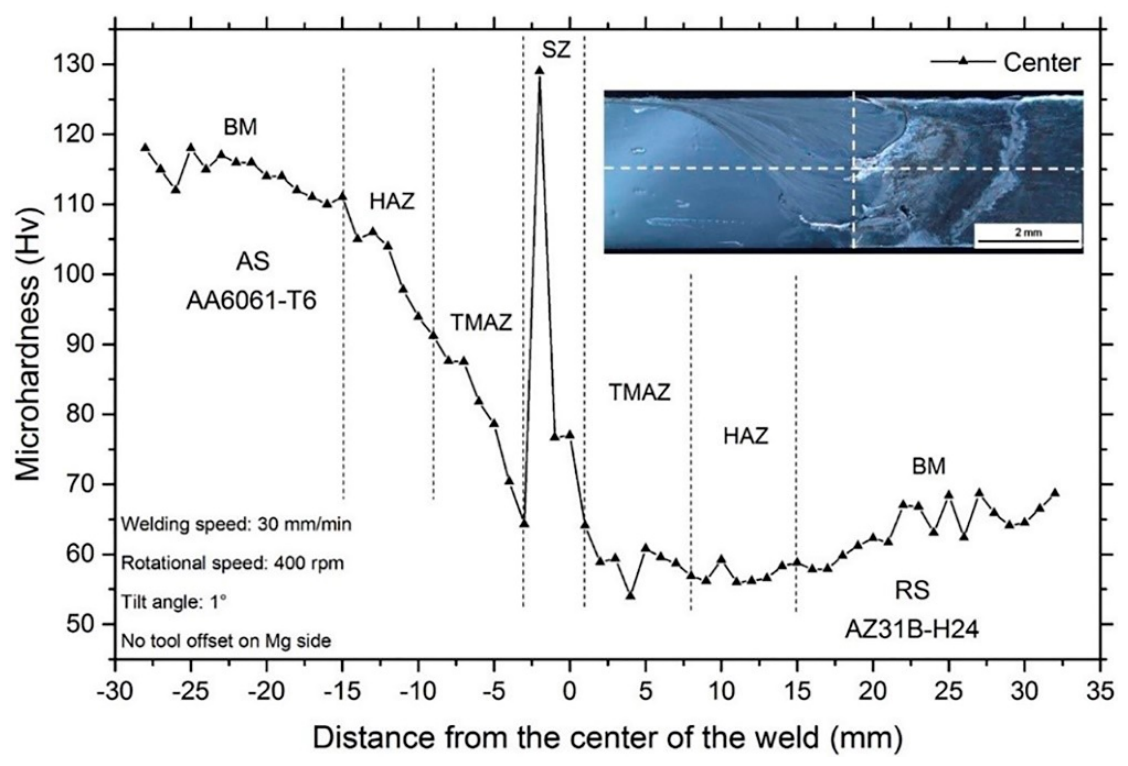

Figure 9. Microhardness profile in joint M7. (BM: base metal; HAZ: heat affected zone; TMAZ: thermomechanically affected zone; SZ: stir zone; AS: advancing side; RS: retreating side). 
A decrease in hardness is also observed in both the heat affected zone (HAZ) and thermomechanically affected zone (TMAZ), with respect to the base metal on the side of the aluminum alloy. The reduction of microhardness values can be related to coarsening, dissolution and re-precipitation of the strengthening particles (i.e. $\mathrm{Mg}_{2} \mathrm{Si}$ ). These observations are based on the thermal cycle experimented during the welding process [27], strength in hardened aluminum alloys depends significantly on the strengthening precipitates rather than on grain size.

Although the temperature was not measured in this study, Venkateswaran et al. [20] reported that dissolution of precipitates occurs when the temperature of $\mathrm{SZ}$ is higher than $400{ }^{\circ} \mathrm{C}$ in joints of AA60063-T5/AZ31B-H24 by FSW. On the other hand, the strength of the strain hardened alloy, AZ31B-H24, depends on the grain size and the level of cold working [28]. The decrease in hardness on the $\mathrm{Mg}$ side can be caused by grain coarsening due to thermal cycle experimented during welding.

Hardness values (95-153 HV) of M3 joints are higher than those obtained in weld M7 (76-129 HV). It can be attributed to a higher amount of intermetallic phases for the greater heat generation caused by the higher rotational speed (1200 RPM vs 400 RPM). Dorbane et al. [1] mentioned that the formation of IMC is related to the heat generation during the FSW process. Additionally, Firouzdor and Kou [8] welded dissimilar AA6061/AZ31-H24 alloys by this process noting that the heat generation is higher for: (1) low welding speed; (2) high rotational speed; (3) placing Al alloy in advancing side; and (4) tool offset in Al.

\subsection{Tensile tests}

The results of tensile test are shown in Table 6. As can be observed, the joints of A6061-T6/AZ31B-H24 have lower tensile strength compared to the base metals (Table 2).

Table 6. Mechanical properties and failure location in $\mathrm{Al} / \mathrm{Mg}$ joint by FSW.

\begin{tabular}{cccc}
\hline & Tensile strength (MPa) & Elongation (\%) & Failure location \\
M3A & 16.9 & 0.096 & Weld \\
M3B & 21.0 & 0.229 & Weld \\
Standard deviation & 2.89 & 0.094 & - \\
Average & 18.95 & 0.162 & - \\
M7A & 88.5 & 0.175 & Weld \\
M7B & 87.9 & 0.171 & Weld \\
Standard deviation & 0.42 & 0.002 & - \\
Average & 88.2 & 0.173 & - \\
\hline
\end{tabular}

In addition, fracture of specimens was located in the weld area and occurred during the test, which suggests that is promoted by the presence of defects in the joint (tunnel and lack of penetration) and the presence of $\mathrm{Al}_{3} \mathrm{Mg}_{2}$ and $\mathrm{Al}_{12} \mathrm{Mg}_{17}$ compounds. On the other hand, the higher tensile strength of joint M7 compared to the one of M3 could be attributed to the complex structure of this weld in the SZ (Figure 3a). It has been mentioned in previous studies [20] that a complex interface in the weld can contribute to the strength of dissimilar joints of $\mathrm{Al} / \mathrm{Mg}$.

Also, Shi et al. [19] observed that as the laminar bands in an intercalated structure is the more curved, the crack deflection will be facilitated during tensile stresses. They also mentioned that the bands should be relatively short and discontinuous to prevent a fast propagation of the crack along the bands.

It is important to mention that formation of IMC involves a higher level of incoherence, which will induce a large accumulation of dislocations during the deformation. Therefore, the crack initiation process will be further accelerated when the weld is subjected to stress loading conditions due to the higher dislocations density [1]. Low elongations and brittle fracture are obtained in both the $\mathrm{M} 3$ and $\mathrm{M} 7$ joints (Table 6), which is related to the presence of hard intermetallic compounds (Al ${ }_{3} \mathrm{Mg}_{2}$ and $\left.\mathrm{Al}{ }_{12} \mathrm{Mg}_{17}\right)$. Similar results have been reported in other studies regarding welding of dissimilar Al and Mg alloys by FSW [1,10-12,19].

\section{Conclusions}

The following conclusions can be drawn from the results obtained in the present investigation:

- $\quad$ Dissimilar AA6061-T6 to AZ31B-H24 alloys can be joined by friction stir welding using different processing parameters. However, of vital importance is the identification of the advancing side and the retreating to have an easier advancement of the tool.

- $\quad$ Defects like tunnel and lack of penetration are more significant when using lower rotational speed (M7 joint) by insufficient heat generation during the process. 
- The stir zone (SZ) of M3 joints was characterized by the presence of eutectic structure and islands with globular morphology, while that of $\mathrm{M} 7$ joint shows an intercalated lamellar structure of $\mathrm{Al}$ and $\mathrm{Mg}$ material. $\mathrm{Al}_{3} \mathrm{Mg}_{2}$ and $\mathrm{Al}_{12} \mathrm{Mg}_{17}$ intermetallic compounds were also observed in SZ of these welds formed.

- $\quad$ The higher hardness values (95-153 Hv) obtained in the M3 joint compared to the M7 weld (76-129 Hv), can be related to a higher amount of IMC.

- Under uniaxial tensile conditions, welds are fractured in the welding zone and exhibit a brittle behavior, which is related to defects such as lack of penetration, tunnel, insufficient mixing, and the presence of compounds $\mathrm{Al}_{3} \mathrm{Mg}_{2}$ and $\mathrm{Al}_{12} \mathrm{Mg}_{17}$ intermetallic compounds.

- The highest tensile strength is obtained in the M7 joint (88.2 MPa), and the lowest (18.95 MPa) in the M3 weld. This behavior is related to a higher amount of IMC when using a higher rotational speed.

\section{Acknowledgements}

Rocio Saldaña-Garcés and Emmanuel José Gutiérrez-Castañeda duly recognize the Cátedra CONACYT assigned at COMIMSA and The Institute of Metallurgy of The Autonomous University of San Luis Potosi, respectively. Daniela Hernández-García gives a special acknowledgment to CONACYT for the Master's degree scholarship and recognizes all the facilities at the AIMEN Technology Center to use the FSW equipment.

\section{References}

[1] Dorbane A, Mansoor B, Ayoub G, Shunmugasamy VC, Imad A. Mechanical, microstructural and fracture properties of dissimilar welds produced by friction stir welding of AZ31B and Al6061. Materials Science and Engineering A. 2016;651:720-733. http://dx.doi.org/10.1016/j.msea.2015.11.019.

[2] Sameer MD, Birru AK. Mechanical and metallurgical properties of friction stir welded dissimilar joints of AZ91 magnesium alloy and AA 6082-T6 aluminium alloy. J. Magnesium Alloys. 2019;7(2):264-271. http://dx.doi.org/10.1016/j.jma.2018.09.004.

[3] Jayaraj RK, Malarvizhi S, Balasubramanian V. Electrochemical corrosion behavior of stir zone of friction stir welded dissimilar joints of AA6061 aluminium-AZ31B magnesium alloys. Transactions of Nonferrous Metals Society of China. 2017;27(10):2181-2192. http://dx.doi.org/10.1016/S1003-6326(17)60244-9.

[4] Li W, Niu PL, Yan SR, Patel V, Wen Q. Improving microstructural and tensile properties of AZ31B magnesium alloy joints by stationary shoulder friction stir welding. Journal of Manufacturing Processes. 2019;37:159-167. http://dx.doi.org/10.1016/j.jmapro.2018.11.014.

[5] Hongtao Z, Xiangyu DAI, Jicai F. Interfacial microstructure and mechanical properties of Al/Mg butt joints made by MIG welding process with Zn-Cd alloys as interlayer. Journal of Wuhan University of Technology-Mater. Science Editor. 2014;29:1258-1264.

[6] Kumar A, Khurana MK, Singh G. Modeling and optimization of friction stir welding process parameters for dissimilar aluminum alloys. Materials Today: Proceedings. 2018;5(11):25440-25449.

[7] Gibson BT, Lammlein DH, Prater TJ, Longhurst WR, Cox CD, Ballun MC, et al. Friction stir welding: Process, automation, and control. Journal of Manufacturing Processes. 2014;16(1):56-73. http://dx.doi.org/10.1016/j.jmapro.2013.04.002.

[8] Firouzdor V, Kou S. Al-to-Mg friction stir welding: effect of material position, travel speed, and rotation speed. Metallurgical and Materials Transactions A: Physical Metallurgy and Materials Science. 2010;41(11):2914-2935. http://dx.doi.org/10.1007/s11661-0100340-1.

[9] Fu B, Qin G, Li F, Meng X, Zhang J, Wu C. Friction stir welding process of dissimilar metals of 6061-T6 aluminum alloy to AZ31B magnesium alloy. Journal of Materials Processing Technology. 2015;218:38-47. http://dx.doi.org/10.1016/j.jmatprotec.2014.11.039.

[10] Masoudian A, Tahaei A, Shakiba A, Sharifianjazi F, Mohandesi JA. Microstructural and mechanical properties of friction stir weld of dissimilar AZ31-O magnesium alloy to 6061-T6 aluminum alloy. Transactions of Nonferrous Metals Society of China. 2014;24(5):13171322. http://dx.doi.org/10.1016/S1003-6326(14)63194-0.

[11] Mohammadi J, Behnamian Y, Mostafaei A, Gerlich AP. Tool geometry, rotation and travel speed effects on the properties of dissimilar magnesium/aluminum friction stir welded lap joints. Materials \& Design. 2015;75:95-112. http://dx.doi.org/10.1016/j.matdes.2015.03.017.

[12] Mohammadi J, Behnamian Y, Mostafaei A, Izadi H, Saeid T, Kokabi AH, et al. Friction stir welding joint of dissimilar materials between AZ31B magnesium and 6061 aluminum alloys: microstructure studies and mechanical characterizations. Materials Characterization. 2015;101:189-207. http://dx.doi.org/10.1016/j.matchar.2015.01.008.

[13] Lee KJ, Kwon EP. Microstructure of stir zone in dissimilar friction stir welds of AA6061-T6 and AZ31 alloy sheets. Transactions of Nonferrous Metals Society of China. 2014;24(7):2374-2379. http://dx.doi.org/10.1016/S1003-6326(14)63359-8. 
[14] Malarvizhi S, Balasubramanian V. Influences of tool shoulder diameter to plate thickness ratio (D/T) on stir zone formation and tensile properties of friction stir welded dissimilar joints of AA6061 aluminum - AZ31B magnesium alloys. Materials \& Design. 2012;40:453-460. http://dx.doi.org/10.1016/j.matdes.2012.04.008.

[15] Azizieh M, Sadeghi Alavijeh A, Abbasi M, Balak Z, Kim HS. Mechanical properties and microstructural evaluation of AA1100 to AZ31 dissimilar friction stir welds. Materials Chemistry and Physics. 2016;170:251-260. http://dx.doi.org/10.1016/j.matchemphys.2015.12.046.

[16] Liang Z, Chen K, Wang X, Yao J, Yang Q, Zhang L, et al. Effect of tool offset and tool rotational speed on enhancing mechanical property of Al/Mg dissimilar FSW joints. Metallurgical and Materials Transactions. A, Physical Metallurgy and Materials Science. 2013;44(8):37213731. http://dx.doi.org/10.1007/s11661-013-1700-4.

[17] Regev M, El Mehtedi M, Cabibbo M, Quercetti G, Ciccarelli D, Spigarelli S. High temperature plasticity of biometallic magnesium and aluminum friction stir welded joints. Metallurgical and Materials Transactions. A, Physical Metallurgy and Materials Science. 2014;45(2):752-764. http://dx.doi.org/10.1007/s11661-013-2034-y.

[18] Sato YS, Park SHC, Michiuchi M, Kokawa H. Constitutional liquation during dissimilar friction stir welding of Al and Mg alloys. Scripta Materialia. 2004;50(9):1233-1236. http://dx.doi.org/10.1016/j.scriptamat.2004.02.002.

[19] Shi H, Chen K, Liang Z, Dong F, Yu T, Dong X, et al. Intermetallic compounds in the banded structure and their effect on mechanical properties of Al/Mg dissimilar friction stir welding joints. Journal of Materials Science and Technology. 2017;33(4):359-366. http://dx.doi.org/10.1016/j.jmst.2016.05.006.

[20] Venkateswaran P, Reynolds AP. Factors affecting the properties of friction stir welds between aluminum and magnesium alloys. Materials Science and Engineering A. 2012;545:26-37. http://dx.doi.org/10.1016/j.msea.2012.02.069.

[21] Abdollahzadeh A, Shokuhfar A, Cabrera JM, Zhilyaev AP, Omidvar H. In-situ nanocomposite in friction stir welding of 6061-T6 aluminum alloy to AZ31 magnesium Alloy. Journal of Materials Processing Technology. 2019;263:296-307. http://dx.doi.org/10.1016/j.jmatprotec.2018.08.025.

[22] Cao X, Jahazi M. Effect of welding speed on the quality of friction stir welded butt joints of a magnesium alloy. Materials \& Design. 2009;30(6):2033-2042. http://dx.doi.org/10.1016/j.matdes.2008.08.040.

[23] Khan NZ, Siddiquee AN, Khan ZA, Shihab SK. Investigation on tunneling and kissing bond defects in FSW joints for dissimilar aluminum alloys. Journal of Alloys and Compounds. 2015;648:360-367. http://dx.doi.org/10.1016/j.jallcom.2015.06.246.

[24] Gerlich A, Su P, Yamamoto M, North TH. Material flow and intermixing during dissimilar friction stir welding. Science and Technology of Welding and Joining. 2008;13(3):254-264. http://dx.doi.org/10.1179/174329308X283910.

[25] ASM International. ASM handbook: alloy phase diagrams. 1st ed. Materials Park, OH: ASM International; 1992.

[26] Li D, Cui Z, Yang Q, Sun B, Sun M. Microstructure and property of friction stir welding joint of 7075Al and AZ31BMg. Journal of Shanghai Jiaotong University. 2012;17(6):679-683. http://dx.doi.org/10.1007/s12204-012-1345-2.

[27] Sato YS, Urata M, Kokawa H. Parameters controlling microstructure and hardness during friction-stir welding of precipitationhardenable aluminum alloy 6063. Metallurgical and Materials Transactions A: Physical Metallurgy and Materials Science. 2002;33(3):625-635. http://dx.doi.org/10.1007/s11661-002-0124-3.

[28] Chowdhury SH, Chen DL, Bhole SD, Cao X, Wanjara P. Friction stir welded AZ31 magnesium alloy: Microstructure, texture, and tensile properties. Metallurgical and Materials Transactions A: Physical Metallurgy and Materials Science. 2013;44(1):323-336. http://dx.doi.org/10.1007/s11661-012-1382-3. 